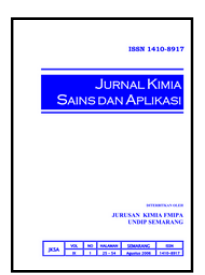

\title{
Pengaruh Substitusi Semen oleh Silika Abu Sekam Padi terhadap Kuat Tekan dan Suhu Reaksi Semen Portland
}

\author{
Adi Darmawan ${ }^{\mathrm{a}}$, Dian Anggraini ${ }^{\mathrm{a}}$, Gunawan ${ }^{\mathrm{a}}$ \\ a Inorganic Chemistry Laboratory, Chemistry Department, Faculty of Sciences and Mathematics, Diponegoro University, Jalan Prof. \\ Soedarto, Tembalang, Semarang 50275 \\ * Corresponding author: adidarmawan@live.undip.ac.id
}

\begin{tabular}{l} 
Article Info \\
\hline Keywords: \\
cement, rice hull, \\
compressive \\
strength and \\
reaction \\
temperature
\end{tabular}

\section{Abstract}

The need of cement for building materials increase sharply, therefore to minimize the use of cement is by the addition of additional aggregate. The aggregate is the rice hull which in the society is not used optimally. By addition of rice hull it is hoped that it could repair compressive strength and reaction temperature of cement. Research on effect of addition rice hull silica to increasing of compressive strength and reaction temperature of Portland cement has been done. The addition of rice hull silica in the Portland cement was done by various composition of rice hulls silica of $0-30 \%$ to weight cement. The result showed that cement compressive strength was influenced by the age of mortar and silica composition. Mortar at 7 days has compressive strength lower than 28 days. The compressive strength was increase for $0-20 \%$ of rice hull silica and decrease between $20-30 \%$ of rice hull silica. The best of compressive strength is as addition of rice hull silica of $3 \%$, and the reaction temperature decreased by addition rice hull silica.

Kata kunci:

Semen, abu sekam, kuat tekan dan suhu reaksi

\begin{abstract}
Abstrak
Kebutuhan semen untuk bahan bangunan semakin meningkat, sehingga untuk meminimalisir penggunaan semen diperlukan agregat tambahan. Agregat tersebut adalah abu sekam padi yang di masyarakat belum dimanfaatkan secara optimal. Dengan penambahan abu sekam padi tersebut dapat memperbaiki kuat tekan dan suhu reaksi semen. Telah dilakukan penelitian pengaruh penambahan silika abu sekam padi terhadap kuat tekan dan suhu reaksi semen Portland. Penambahan silika abu sekam padi ke dalam semen Portland dilakukan dengan variasi komposisi silika abu sekam padi antara $0 \%-30 \%$ terhadap berat semen. Hasil penelitian menunjukkan bahwa kuat tekan semen dipengaruhi umur mortar dan komposisi silika. Mortar pada umur 7 hari memiliki kuat tekan yang lebih rendah daripada umur 28 hari. Kuat tekan meningkat antara $0-20 \%$ dan mengalami penurunan pada $20-30 \%$. Kuat tekan yang paling optimal diperoleh pada penambahan silika abu sekam padi sebesar $3 \%$, sedangkan suhu reaksi cenderung menurun dengan penambahan silika abu sekam padi.
\end{abstract}

\section{Pendahuluan}

Kepulauan Indonesia memiliki kekayaan alam berupa mineral dan bahan baku terutama untuk keramik, campuran semen dan lain-lain yang merupakan bahan dasar penyusun kerak bumi seperti $\mathrm{SiO}_{2}, \mathrm{Al}_{2} \mathrm{O}_{3}, \mathrm{CaO}, \mathrm{Fe}_{2} \mathrm{O}_{3}$ dan $\mathrm{MgO}$. Semen merupakan hasil industri dari paduan bahan baku: batu kapur/gamping sebagai bahan utama dan lempung/tanah liat atau bahan pengganti lainnya dengan hasil akhir berupa padatan berbentuk bubuk/bulk, tanpa memandang proses pembuatannya, yang mengeras atau membatu setelah bercampur dengan air. Pada tahun 1824, orang Inggris, Joseph Aspadin mendapatkan paten untuk semen buatan yang dibuat dengan memanaskan batu gamping 
argilaseo yang dinamakan dengan nama Semen Portland [1].

Ada beberapa bahan campuran yang memiliki sifat hidrolis seperti silika abu sekam padi yang dibuat dari sekam padi yang dipakai untuk campuran semen. Penelitian [2-4] menunjukkan bahwa abu sekam padi banyak mengandung silika.

Pengaruh penambahan abu sekam padi (banyak mengandung silika) yang bereaksi dengan semen akan menyebabkan kuat tekan semen semakin tinggi dan suhu reaksi semakin rendah [5]. Menurut Zulhadjri, $d k k$. [5] penggunaan abu sekam padi sebagai pozzolan buatan pada semen PPC (Portland Pozzolan Cement) menyebabkan semen memiliki sifat yang lebih baik dari semen biasa yang sifatnya mudah mengeras dan mudah patah. Dari hasil penelitian menunjukkan penambahan pozzolan buatan dari abu sekam padi memberikan pengaruh yang besar terhadap kuat tekan, di mana kuat tekan maksimum diperoleh pada semen PPC dengan pozzolan abu sekam padi hasil pemanasan pada suhu $700^{\circ} \mathrm{C}$.

Pada penelitian ini dilakukan pengujian terhadap sifat-sifat fisis semen Portland akibat penambahan silika buatan dari sekam padi pada semen Portland yang dititikberatkan pada: kuat tekan dan suhu reaksi. Kuat tekan ini diukur pada hari ke 7 dan ke 28 supaya terlihat perbedaannya. Diduga dengan penambahan abu sekam padi kuat tekan semen meningkat dan suhu reaksi menurun.

\section{Metode Penelitian}

Peralatan: Alat yang digunakan dalam penelitian ini antara lain pengayakan 10 mesh, pengayakan 200 mesh, timbangan analisis, stop wacth, termometer, cetakan mortar ukuran $(5 \times 5 \times 5) \mathrm{cm}^{3}$ baja 55 HRB kedap air, oven, spatula, mangkok pengaduk, mesin pengaduk standar ASTM C 305, dan peralatan gelas yang lazim digunakan di laboratorium. Untuk keperluan analisis kuat tekan digunakan alat compression test, dan untuk analisis suhu reaksi semen digunakan termometer.

Bahan: Bahan yang digunakan dalam penelitian ini adalah semen Tiga Roda Indocement, pasir, air dan sekam padi

\section{Pembuatan Silika Abu Sekam.}

Sekam padi dikeringkan di bawah sinar matahari kemudian dibersihkan dari kotoran yang berupa ranting dan kerikil sehingga diperoleh sekam padi yang kering dan bersih. Sekam padi yang kering dan bersih kemudian dipanaskan di atas kompor hingga menjadi arang sekam padi. Arang hitam yang sudah terbentuk kemudian diabukan dengan memasukkan ke dalam cawan porselen untuk selanjutnya dipanaskan dalam furnace pada suhu $700^{\circ} \mathrm{C}$ selama 3 jam. Silika yang sudah terbentuk diayak dengan ayakan no 200 dengan ukuran 75 mikron untuk mendapatkan silika abu sekam yang diinginkan.

\section{Pembuatan Mortar Semen.}

Secara terpisah komposisi bahan disiapkan untuk 6 benda uji, Sebanyak $242 \mathrm{~mL}$ akuades dimasukkan ke dalam mangkok pengaduk kemudian ditambahkan semen dan kaca sesuai dengan komposisi (komposisi tercantum pada tabel 1), Selanjutnya dilakukan pengocokan dengan kecepatan 140 rpm selama 30 detik, kemudian ditambahkan pasir dilakukan pengocokan dengan kecepatan 140 rpm selama 30 detik, dilanjutkan pengocokan dengan kecepatan $285 \mathrm{rpm}$ selama 30 detik, dan dilakukan pembersihan mortar yang menempel di pinggir mangkok selama 75 detik. Selanjutnya dilakukan pengocokan kembali dengan kecepatan 285 rpm selama 1 menit, dan didiamkan selama 30 detik. kemudian mortar dicetak pada cetakan mortar dengan menumbuk 32 x selama 10 detik menggunakan spatula sebanyak 2 lapis, dan selanjutnya Cetakan didiamkan atau direndam dalam air selama 7 hari dan 28 hari dan dilakukan pengukuran kuat tekan dengan menggunakan compression test.

Tabel 1. Komposisi mortar semen

\begin{tabular}{cccc}
\hline $\begin{array}{c}\text { Pasir } \\
\text { (gram) }\end{array}$ & $\begin{array}{c}\text { Semen } \\
\text { (gram) }\end{array}$ & $\begin{array}{c}\text { Silika abu } \\
\text { sekam padi } \\
\text { (gram) }\end{array}$ & $\begin{array}{c}\text { Akuades } \\
(\mathrm{mL})\end{array}$ \\
\hline 1375 & 500 & 0 & 242 \\
1375 & 485 & 15 & 242 \\
1375 & 470 & 30 & 242 \\
1375 & 455 & 45 & 242 \\
1375 & 440 & 60 & 242 \\
1375 & 425 & 75 & 242 \\
1375 & 410 & 90 & 242 \\
1375 & 395 & 105 & 242 \\
1375 & 380 & 120 & 242 \\
1375 & 365 & 135 & 242 \\
1375 & 350 & 150 & 242 \\
\hline
\end{tabular}

*Setiap variasi komposisi digunakan untuk 6 benda uji ( 3 untuk pengukuran kuat tekan pada hari ke 7 dan 3 untuk hari ke 28).

\section{Pengukuran Suhu Reaksi Semen}

Secara terpisah komposisi masing-masing dari jenis kaca ditambahkan ke dalam komposisi semen, selanjutnya diaduk hingga merata. Campuran kaca dan semen yang telah dipisahkan kemudian masing-masing ditambahkan air dengan volume yang sama $(40,33 \mathrm{~mL}$ untuk $1 \mathrm{x}$ benda uji). Setelah campuran direaksikan dengan air maka akan timbul panas pada campuran, yang kemudian diukur dengan menggunakan termometer.

\section{Hasil dan Pembahasan}

Dalam penelitian ini, mortar dibentuk dengan mereaksikan air, semen, pasir, dan ditambahkan suatu agregat halus silika abu sekam padi. Komposisi semen yang paling dominan memberikan sifat semen adalah 
trikalsium silikat $\left(3 \mathrm{CaO} . \mathrm{SiO}_{2}\right)$ dan dikalsium silikat $\left(2 \mathrm{CaO} . \mathrm{SiO}_{2}\right)$ [6]. Bubur semen hasil dari pencampuran silika abu sekam padi mengandung campuran yang sangat higroskopis. Saat semen dan silika abu sekam padi berinteraksi/bereaksi dengan air disebut proses hidrasi, dan hasilnya dinamakan hidrasi semen. Senyawa $3 \mathrm{CaO} \mathrm{SiO}_{2}$ jika terkena air akan cepat bereaksi dan menghasilkan panas, sedangkan senyawa $2 \mathrm{CaO} \mathrm{SiO}_{2}$ lebih lambat bereaksi dengan air dan hanya berpengaruh terhadap semen setelah umur 7 hari. Saat semen berinteraksi dengan air akan terbentuk gel kalsium silikat hidrat/gel tobermorite dan Portlandit sesuai dengan persamaan reaksi berikut:

$$
\begin{aligned}
& 6 \mathrm{CaO} .2 \mathrm{SiO}_{2}+6 \mathrm{H}_{2} \mathrm{O} \rightarrow 3 \mathrm{CaO} .2 \mathrm{SiO}_{2} \cdot 3 \mathrm{H}_{2} \mathrm{O}+3 \mathrm{Ca}(\mathrm{OH})_{2} \\
& 4 \mathrm{CaO} .2 \mathrm{SiO}_{2}+4 \mathrm{H}_{2} \mathrm{O} \rightarrow 3 \mathrm{CaO} .2 \mathrm{SiO}_{2} \cdot 3 \mathrm{H}_{2} \mathrm{O}+\mathrm{Ca}(\mathrm{OH})_{2}
\end{aligned}
$$

fasa silikat gel tobermorite Portlandit

Senyawa $3 \mathrm{CaO} \mathrm{SiO}_{2}$ membebaskan kalsium hidroksida hampir tiga kali dari yang dibebaskan oleh $2 \mathrm{CaO} . \mathrm{SiO}_{2}$. Hidrasi $3 \mathrm{CaO} . \mathrm{SiO}_{2}$ sangat berpengaruh pada saat proses pengerasan dan pengembangan awal kekuatan semen sedangkan hidrasi $2 \mathrm{CaO} \mathrm{SiO}_{2}$ berpengaruh pada akhir kekuatan semen. Jika kandungan $3 \mathrm{CaO} \mathrm{SiO}_{2}$ lebih banyak maka akan terbentuk semen dengan kekuatan awal yang tinggi dan suhu reaksi yang tinggi, sehingga semen berkualitas rendah. Hal ini dapat dilihat pada saat pencetakan semen yaitu semen mempunyai kuat tekan yang rendah sehingga mudah retak. Sebaliknya jika kandungan $2 \mathrm{CaO} . \mathrm{SiO}_{2}$ lebih banyak maka akan terbentuk semen dengan kekuatan tekan awal yang rendah dan suhu reaksi yang rendah, sehingga semen berkualitas tinggi. Hal ini dapat dilihat pada saat pemakaian semen yaitu hasilnya, semen mempunyai kuat tekan yang tinggi [6].

\section{Pengukuran Kuat Tekan}

Hasil kuat tekan yang didapat dalam penelitian ini disajikan pada tabel 2 dan gambar 1 :

\begin{tabular}{|c|c|c|c|c|c|c|}
\hline $\begin{array}{c}\% \\
\text { Silika }\end{array}$ & $\begin{array}{c}\text { Umur } \\
\text { Mortar } \\
\text { (Hari) }\end{array}$ & $\begin{array}{l}\text { Beban } \\
\text { (Ton) }\end{array}$ & $\begin{array}{c}\text { Kuat } \\
\text { Tekan } \\
\left(\mathrm{N} / \mathrm{mm}^{2}\right)\end{array}$ & $\begin{array}{l}\text { Umur } \\
\text { Mortar } \\
\text { (Hari) }\end{array}$ & $\begin{array}{l}\text { Beban } \\
\text { (Ton) }\end{array}$ & $\begin{array}{c}\text { Kuat } \\
\text { Tekan } \\
\left(\mathrm{N} / \mathrm{mm}^{2}\right)\end{array}$ \\
\hline 0 & 7 & 5,33 & 20,91 & 28 & 10,9 & 42,76 \\
\hline 3 & 7 & 9,06 & 35,54 & 28 & 14,83 & 58,17 \\
\hline 6 & 7 & 7,10 & 27,85 & 28 & 9,67 & 37,93 \\
\hline 9 & 7 & 6,50 & 25,50 & 28 & 9,57 & 37,54 \\
\hline 12 & 7 & 6,20 & 24,32 & 28 & 11,67 & 45,78 \\
\hline 15 & 7 & 5,95 & 23,38 & 28 & 9,87 & 38,72 \\
\hline 18 & 7 & 7,30 & 28,64 & 28 & 9,43 & 36,99 \\
\hline 21 & 7 & 3,73 & 14,51 & 28 & 6,43 & 25,22 \\
\hline 24 & 7 & 1,33 & 5,22 & 28 & 3,17 & 12,43 \\
\hline 27 & 7 & 1,57 & 6,16 & 28 & 2,07 & 8,12 \\
\hline 30 & 7 & 0,133 & 0,52 & 28 & 2,60 & 10,20 \\
\hline
\end{tabular}

Tabel 2. Kuat Tekan Mortar Semen

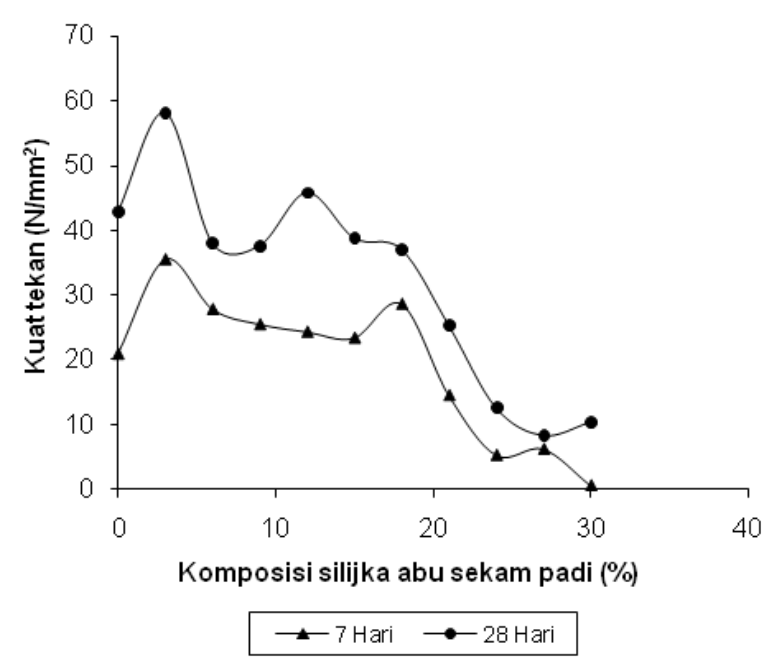

Gambar 1. Hubungan komposisi silika dan kuat tekan mortar semen

Dari tabel 2 dan gambar 1 di atas dapat dilihat bahwa mortar pada umur 7 hari memiliki kuat tekan lebih rendah daripada yang 28 hari (pada penambahan silika $0 \%$ pada umur 7 hari kuat tekan $20,91 \mathrm{~N} / \mathrm{mm}^{2}$ dan pada umur 28 hari $42,76 \mathrm{~N} / \mathrm{mm}^{2}$ ). Salah satu faktor yang mempengaruhi kuat tekan semen atau mortar yaitu umur mortar. Dengan meningkatnya umur mortar semen, kuat tekan meningkat, hal ini disebabkan adanya proses hidrasi lebih lanjut dari komponen semen dan silika abu sekam padi yang belum terhidrasi secara sempurna sehingga bersamaan dengan adanya $\mathrm{H}_{2} \mathrm{O}$ terbentuk gel kalsium silikat hidrat yang menyebabkan kuat tekan meningkat.

Faktor yang kedua yaitu penambahan silika. Dengan penambahan abu sekam padi, kandungan silika di dalam semen akan meningkat. Silika dari abu sekam padi tersebut berikatan dengan kalsium hidroksida yang dilepaskan oleh semen pada saat bereaksi dengan air. Jadi semakin banyak penambahan abu sekam padi maka silika yang berikatan dengan kalsium hidroksida semakin banyak, sehingga kuat tekan meningkat [5]. Reaksi antara silika dengan air dapat dilihat pada reaksi di bawah ini:

$$
\begin{array}{ll}
6 \mathrm{CaO} .2 \mathrm{SiO}_{2}+6 \mathrm{H}_{2} \mathrm{O} \rightarrow & 3 \mathrm{CaO} .2 \mathrm{SiO}_{2} \cdot 3 \mathrm{H}_{2} \mathrm{O}+3 \mathrm{Ca}(\mathrm{OH})_{2} \\
\mathrm{Ca}(\mathrm{OH})_{2} & \rightarrow \mathrm{Ca}^{2+}+2(\mathrm{OH})^{-} \\
\mathrm{Ca}^{2+}+2(\mathrm{OH})^{-}+\mathrm{SiO}_{2} \rightarrow & {\mathrm{CaO} . \mathrm{SiO}_{2} \cdot \mathrm{H}_{2} \mathrm{O}} \\
\text { kalsium silikat hidrat [7] }
\end{array}
$$

Setelah ditambahkan silika abu sekam padi dengan komposisi 3\% sampai 30\% didapat kuat tekan yang berbeda-beda. Kuat tekan yang paling optimal didapat pada penambahan $3 \%$ silika abu sekam padi yaitu sebesar 35,54 N/mm² pada umur 7 hari dan 58,17 N/mm² pada umur 28 hari.

Pada penambahan $20 \%$ ke atas silika abu sekam padi, kuat tekan mengalami penurunan. Hal ini karena 
semen yang berfungsi sebagai perekat jumlahnya semakin sedikit. Selain itu jumlah kalsium hidroksida hasil reaksi hidrasi semen portland lebih sedikit sehingga banyak silika yang tidak bereaksi dengan kalsium hidroksida. Silika abu sekam padi banyak yang mengendap. Hasil ini sesuai dengan penelitian sebelumnya [5] yang menyatakan hasil kuat tekan meningkat dari penambahan $0 \%$ sampai dengan $20 \%$.

\section{Pengukuran Suhu reaksi}

Pada penelitian ini dilakukan pengukuran suhu reaksi dengan cara mencampurkan semen dan silika abu sekam padi dengan persentase 3, 6, 9, 12, 15, 18, 21, 24, 27 , dan $30 \%$ dari berat semen yang diperlukan yaitu 500 gram, dengan dibandingkan semen yang tanpa ditambah silika abu sekam padi. Semen dan silika abu sekam padi yang sudah disiapkan dimasukkan ke dalam suatu wadah, selanjutnya ditambah dengan akuades kemudian dilihat kenaikan suhunya pada termometer. Hasil yang diperoleh dapat dilihat pada tabel 3 berikut ini:

Tabel 3 Suhu Reaksi

\begin{tabular}{cccc}
\hline $\begin{array}{c}\text { Berat Silika } \\
(\%)\end{array}$ & $\begin{array}{c}\text { Suhu awal } \\
\left({ }^{\circ} \mathrm{C}\right)\end{array}$ & $\begin{array}{c}\text { Suhu akhir } \\
\left({ }^{\circ} \mathrm{C}\right)\end{array}$ & $\begin{array}{c}\Delta \mathrm{T} \\
\left({ }^{\circ} \mathrm{C}\right)\end{array}$ \\
\hline 0 & 27,9 & 29,5 & 1,6 \\
3 & 27,9 & 29,4 & 1,5 \\
6 & 27,9 & 29,3 & 1,4 \\
9 & 27,9 & 29,2 & 1,3 \\
12 & 27,9 & 29,1 & 1,2 \\
15 & 27,9 & 29,0 & 1,1 \\
18 & 27,9 & 28,9 & 1 \\
21 & 27,9 & 28,9 & 1 \\
24 & 27,9 & 29,0 & 1,1 \\
27 & 27,9 & 29,1 & 1,2 \\
30 & 27,9 & 29,1 & 1,2 \\
\hline
\end{tabular}

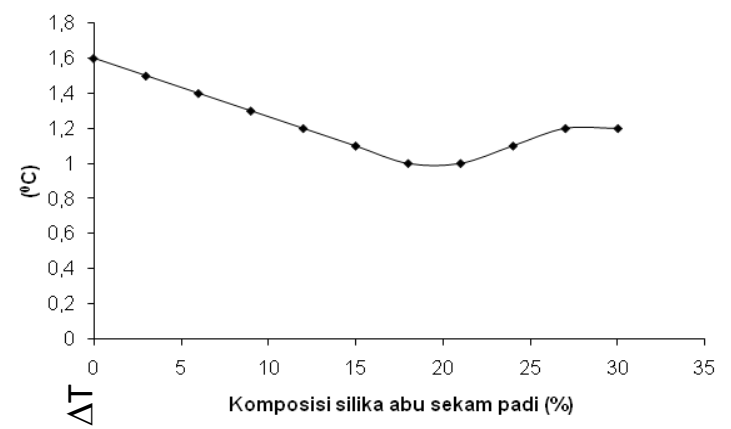

Gambar 2. Hubungan komposisi silika abu sekam padi dengan suhu reaksi

Suhu reaksi yang didapat dari hasil pengukuran hampir sama yaitu sekitar suhu ruang. Suhu reaksi yang didapatkan dari penelitian lebih baik jika dibandingkan yang tanpa penambahan silika abu sekam padi, walaupun penurunan suhu reaksinya tidak signifikan tetapi dengan penambahan silika abu sekam padi suhu reaksi menurun. Suhu reaksi yang paling optimum pada saat penambahan silika abu sekam padi pada $\Delta \mathrm{T}=1^{\circ} \mathrm{C}$ dengan penambahan silika abu sekam padi $18 \%$ dan $21 \%$ [5].

Tinggi rendahnya suhu reaksi dipengaruhi oleh kandungan $3 \mathrm{CaO} . \mathrm{SiO}_{2}$ dan $2 \mathrm{CaO} . \mathrm{SiO}_{2}$. Senyawa $3 \mathrm{CaO} . \mathrm{SiO}_{2}$ sifatnya lebih cepat mengalami hidrasi daripada senyawa lainnya. Semakin tinggi kandungan $3 \mathrm{CaO} \cdot \mathrm{SiO}_{2}$ proses hidrasi yang terjadi lebih besar sehingga kalor yang dilepas juga besar. Pada suhu reaksi yang rendah dipengaruhi oleh kandungan $2 \mathrm{CaO} . \mathrm{SiO}_{2}$ yang tinggi yang menyebabkan pengerasan semen lambat sehingga panas/kalor yang dilepas rendah. Jadi semakin tinggi kandungan silika abu sekam padi dalam semen suhu reaksi semakin rendah [6].

Berkurangnya pembentukan ettringite dengan mengeliminasi $\mathrm{Ca}(\mathrm{OH})_{2}$ dari hasil reaksi $\mathrm{C}_{3} \mathrm{~S}\left(3 \mathrm{CaO} . \mathrm{SiO}_{2}\right)$ dan $\mathrm{C}_{2} \mathrm{~S}\left(2 \mathrm{CaO} . \mathrm{SiO}_{2}\right)$ dengan air yaitu dengan jalan pengikatan $\mathrm{Ca}(\mathrm{OH})_{2}$ oleh silika amorf membentuk kalsium silikat hidrat (semen gel) baru. Meningkatkan kekedapan melalui pembentukan kalsium silikat hidrat (semen gel) baru dengan reaksi sebagai berikut:

$3 \mathrm{CaO} \mathrm{SiO}_{2}+\mathrm{SiO}_{2}+3 \mathrm{H}_{2} \mathrm{O} \rightarrow 3 \mathrm{CaO} \cdot 2 \mathrm{SiO}_{2} \cdot 3 \mathrm{H}_{2} \mathrm{O} \Delta \mathrm{H}=111,32 \mathrm{~kJ}$

Semakin banyak silika yang bereaksi dengan $\mathrm{Ca}(\mathrm{OH})_{2}$ maka kalsium silikat hidrat yang terbentuk lebih banyak dan suhu reaksi semakin menurun [5].

Pada pengukuran suhu reaksi dengan penambahan silika abu sekam padi, suhu reaksinya menurun bila dibandingkan dengan semen yang tanpa ditambah dengan silika abu sekam padi. Besarnya suhu reaksi setiap kenaikan jumlah silika yang ditambahkan, suhu reaksinya menurun. Reaksi yang terjadi adalah reaksi endothermis karena besarnya $\Delta \mathrm{H}$ reaksi yang dihasilkan + seperti pada reaksi di atas.

Dengan suhu reaksi yang rendah akan mempermudah pengerjaan mortar. Karena suhu dapat menyebabkan berkurangnya kekuatan (strenght) dan kekakuan (stiffness) dari elemen-elemen atau sistem struktur. Kombinasi dari tegangan yang terjadi pada bahan akibat suhu dan pembebanan lainnya yang bekerja pada struktur, dapat melebihi tegangan ijin bahan, sehingga dapat membahayakan keamanan struktur. Pada suhu yang terlalu tinggi, pengaruh suhu akan menyebabkan pengembangan atau pemuaian dari bahan. Pemuaian volume dari bahan yang terkekang akan menyebabkan bertambahnya tegangan pada elemen-elemen struktur, sehingga tegangan di dalam elemen akan meningkat. Pada suhu yang tinggi akan mengakibatkan berkurangnya tingkat kelenturan bahan [8].

\section{Kesimpulan}

Berdasarkan hasil penelitian dan pembahasan dapat disimpulkan bahwa kuat tekan semen dipengaruhi oleh umur mortar dan komposisi silika. Mortar pada umur 7 hari memiliki kuat tekan yang lebih rendah daripada umur 28 hari. Kuat tekan meningkat antara 0-20\% dan 
mengalami penurunan pada $20-30 \%$. Kuat tekan yang paling optimal diperoleh pada penambahan silika abu sekam padi sebesar $3 \%$, sedangkan suhu reaksi cenderung menurun dengan penambahan silika abu sekam padi.

\section{Daftar Pustaka}

[1] W. Samekto, C. Rahmadiyanto, Teknologi beton, Kanisius, Yogyakarta, (2001).

[2] D.F. Houston, Rice: Chemistry and Technology, American Association of Cereal Chemists, 1972.

[3] N. Hara, S. Samrejprasong, S. Uparisajkul, H. Noma, Utilization of agro-wastes for building materials, ITIT Project Report, 8.

[4] S. Shofiyatun, Optimasi Sintesa Serbuk Keramik SiC dari Bahan Baku Silika Amorf, in, Universitas Brawijaya, Malang, 2000.

[5] Zulhadjri, N. Jamarun, Z. Zuki, Pembuatan Silika Dari Sekam Padi, in, Lembaga Penelitian Universitas Andalas, 2000.

[6] T. Mulyono, Teknologi beton, Yogyakarta: Andi, (2004).

[7] H. Gunawan, Pengaruh Penambahan Abu Terbang terhadap Kuat Tekan Mortar Kaca, in: Laporan Penelitian, Universitas Riau, Riau, 1995.

[8] K. Tjokrodimuljo, Teknologi beton, Nafiri, Yogyakarta, (1996) 56-57. 